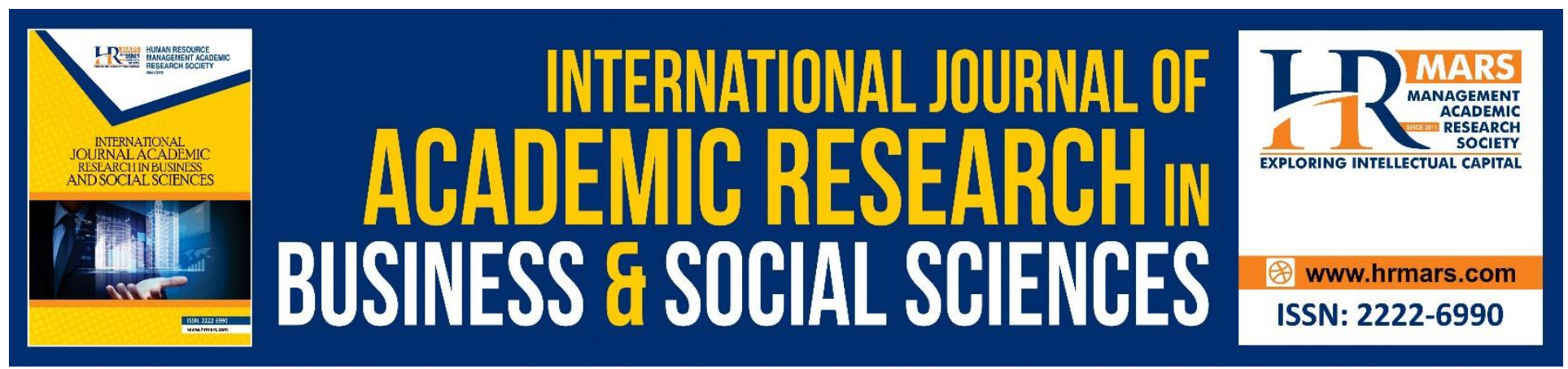

\title{
Role of People Who Left Behind in Public Space: A Case Study of The Wife of International Migrant
}

\author{
Suvimon Khamnoi, Dusadee Ayuwat
}

To Link this Article: http://dx.doi.org/10.6007/IJARBSS/v10-i14/7687

DOI:10.6007/IJARBSS/v10-i14/7687

Received: 08 April 2020, Revised: 20 May 2020, Accepted: 16 June 2020

Published Online: 25 June 2020

In-Text Citation: (Khamnoi \& Ayuwat, 2020)

To Cite this Article: Khamnoi, S., \& Ayuwat, D. (2020). Role of People Who Left Behind in Public Space: A Case Study of The Wife of International Migrant. International Journal of Academic Research in Business and Social Sciences, 10(14), 181-189.

\section{Copyright: @ 2020 The Author(s)}

Published by Human Resource Management Academic Research Society (www.hrmars.com)

This article is published under the Creative Commons Attribution (CC BY 4.0) license. Anyone may reproduce, distribute, translate and create derivative works of this article (for both commercial and non-commercial purposes), subject to full attribution to the original publication and authors. The full terms of this license may be seen

at: http://creativecommons.org/licences/by/4.0/legalcode

Special Issue: WSTI2018 - Issues and Trends on Education, Science and Technology, 2020, Pg. 181 - 189 http://hrmars.com/index.php/pages/detail/IJARBSS

Full Terms \& Conditions of access and use can be found at http://hrmars.com/index.php/pages/detail/publication-ethics 




\title{
Role of People Who Left Behind in Public Space: A Case Study of The Wife of International Migrant
}

\author{
Suvimon Khamnoi ${ }^{1}$, Dr. Dusadee Ayuwat ${ }^{2}$ \\ Department of Social Sciences, Division of Sociology, and Anthropology Labour and International \\ Migration Service Center, Faculty of Humanities and Social Sciences, Khon Kaen University, Khon \\ Kaen, Thailand \\ Email: 2dusayu@kku.ac.th
}

\begin{abstract}
This article explores the roles, in the public space, of women who are left behind by migration. Qualitative research was applied to collect data. The results found that women left behind by migration played larger roles in the community, such as village development activities and community merit making, after receiving their overseas remittance. These activities led them to become loan lenders and labour brokers. Their new positions provided more opportunities to take a role in politics at the local level.
\end{abstract}

Keywords: Women's Role, Public Space, Left Behind.

\section{Introduction}

International migration by Thai workers has been an ongoing phenomenon in Thai society. Despite the increase in economic growth rate of industry and the service sector in Thailand, with the associated increased demands upon the domestic labor force, many people still expect to work abroad due to the higher income they can earn than from domestic employment. International migration has become a favoured activity, especially among workers from the Northeast region of Thailand, who are mostly married, male workers. According to a report from the National Statistics Office (2014), the percentage of married labourers was 60 percent of all Thai international workers. This percentage illustrates the issue of the wives of international migrants being left behind.

International migration by male workers, the husbands of the wives left behind, is a major condition that pushes the wives to take the major role in household activities such as housekeeping, child raising, etc. These tasks may be described as 'domestic work'. When the husbands migrate to work abroad, many household tasks are shifted to become the wife's responsibility. Wives have to undertake household and community tasks in the absence of their husbands. For instance, participating in village meetings, or contacting agencies related to the husband's international migration in order to maintain their social status within the community. 
Therefore, it is interesting to explore how the international migrant's wives, as household representatives, undertake their roles in the public space. This paper argues the concept of gender role, particularly the division of household tasks by gender, and attempts to debate a Thai traditional value, patriarchy, that gives priority to a male person as the household head, and presents more roles, than for women, in public life. This paper, therefore, focuses on the representation of women's roles in public life after their husbands have migrated to work abroad. The implication of the research will be useful in an approach to policies for improving the potential of the wives who have been left behind.

\section{Research Objective}

To investigate the roles of rural Thai women, whose husbands are working abroad, in the public space.

\section{Literature Review}

This paper implements the concept of gender roles, and international migration in a theoretical framework. The details of each of the concepts implemented are as follows.

Gender roles: Gender role is a concept developed by theorists in the $20^{\text {th }}$ Century. The concept focuses on the roles of male and female within the family. The approach of this analysis has been based on the Structural-Functionalism theory. Parson and Bales (1955) suggested that family members are able to live together because each person is assigned to undertake different family activities. When the family have children, the primary care of the children (through pregnancy and childbirth) and housekeeping tasks are undertaken by women (wife and mother). While the men, father or husband, are responsible for providing the safety of the family members and act as the breadwinner of the family. This is a nature-based division of labor within the family (Samutchak et al, 2017). The division of gender role is defined by sex, which represents male and female based on their bio-characteristics. Individuals, either male or female, have a designated reproductive function, and they have different personalities. However, the definition of sex from the socio-cultural view does not only look at sex by biological appearance, but also it is socially constructed by the socio-cultural conditions which determine the appropriate behaviors of the male and female. In conclusion, it is evident that gender roles are designated to male and female based on their biological appearance and socio-cultural contexts in order to present their roles in line with the expectations of society.

Gender role is also explained by feminism theorists. The explanation has been delivered under the emergence of the patriarchal society. Gender roles are represented in social areas and are divided into 2 parts; 1) private area; which is generally within the household boundary. Most private areas are maintained by women who are responsible for household activities such as cooking, housekeeping, and also include biological reproductive activity and cultural reproductive activity such as parenting of children. The parenting process is an activity that occurs within the household or private area. Then there is 2) social area, or the public area, which represents socio-economic activity and political activity. These are activities where the male person plays the major role, for instance, working for income, and membership of organizations, participating in community activities or political activity from which women are excluded. These activities are tied to the biological appearance of the male, so it is noticed that the social area is the men's area, presenting their dominant power over women (Walby, 1991). 
Therefore, gender roles are determined by society. In each society, people are different, and gender roles can change depending on the socio-cultural contexts and the appropriation of the role taken. Moreover, gender roles also relate to the opportunities that individuals take in order to access, use, and control resources, since they have rights, power, responsibility, and expectation, from society, in different objectives. Therefore, gender roles by social determination have a great impact on the status of male and female in such societies (Limanon, 1999; Alesina, Giuliano and Nunn, 2013).

Considering public space in accordance with the gender role concept, public space means the community area that allows community members to participate in community activities, individually, or as a family representative. Moreover, women are able to play an equal role in political activities, as the men. There is an argument Thai society relies on masculinity. However, the current social context has been changed. The gender role is constructed by socio-cultural processes, and an individual's behaviors and actions are socialized by social institutions such as families, schools, media, etc. (Archawanichkul and Thongsima, 2005). In this study, the concept of gender role is applied to consider the gender role of women, whose husbands are working abroad, through the community activities and political activities that they participate in.

International migration: International migration is one type of migration. It is labor movement from one country to another country in order to conduct economic activity. Normally, international principle determines that living in other places for one year is considered a migration. (Chantavanich et al., 1998). The neo-classic economists (Todaro, 1976) explained that individuals make a decision on migration for economic purposes. The crucial pull factors that attract migrants include higher wages and better job opportunities. In the sociological view, international migration has been linked to factors regarding social, culture, legal, and international politics. In addition, migrants generally travel to work in the destination country by way of social networks, or other channels that facilitate international migration.

International migration has socio-economic impacts upon the migrants themselves, to their households at the places of origin, and also upon the people left behind (Champaklay, 2013). Households, that the migrant members frequently send remittances to, would gain more acceptances from their neighbors and communities. In some cases, migrants are respected with gratitude, being good people that are responsible for taking care of the other household members in the origin area (Boonkwang, 2016). Moreover, households that receive remittances frequently would be happier than households without remittances (Chamratrithirong, 2007). International work migration also impacts on changes in the women's role. Datta and Mishra (2011) suggested that when their husbands are working abroad, women have to shoulder the workload of household activity. They play more roles in agricultural tasks while taking care of their children at the same time. They spend more time working because they are responsible for multiple tasks. Some women have to work outside their community, for instance, working in a factory (Karymshakov and Sulaimanova, 2017). Therefore, they have to perform the roles of motherhood and fatherhood, at the same time (Perraudin, 2016).

It can be seen that international work migration, by their husbands, has caused the wives who are left behind to adopt roles in the public space in order to maintain their household's status in the community, and for their own livelihoods. This research views public space through the activities that the women participated in, being, local politics, community, and religious activities. 


\section{Research Methodology}

This paper investigated the role in the public space, of the women whose husbands work abroad. Qualitative methodology was applied to the research design to explore the phenomenon. Key informants were divided into 2 groups that include 1) the community leaders; who were the community headmen, members of The Sub-district Administrative Organization, a total of 10 persons. This informant group provided information regarding the recent situation of male worker's international migration and the general context of the households of women whose husbands work abroad. Another group of key informants was 15 married women whose husbands had been working abroad for at least 1 year. Key informants were women who lived in, either the nuclear household, or the expanded household. In-depth interview was used with this informant group in order to explore the roles of the women. The research area was Kho Tai Sub-district, Sawang Daendin District, in Sakon Nakhon Province. In-depth interview guideline and non-participatory observation were used to collect data, triangulation was applied to crosscheck the data by multiple data sources (Photisita, 2009). Data analysis applied the content analysis method to analyze the role in the public space of the women whose husbands were working abroad.

\section{Research Results}

The results consisted of 2 parts including 1 ) the background of the women whose husbands were working abroad, and 2) the roles in the public space, of women whose husbands were working abroad. The results are presented as follows.

\section{Background of the women whose husbands work abroad}

The women in this research were aged between $25-50$ years old. Their education background ranged from elementary school to Bachelor degree level, so they presented different skills and knowledge on working, use of technology, and leadership. Their husbands had mostly worked abroad for between 1-10 years, in Asian destinations such as South Korea, Taiwan, Japan, Singapore, and Israel. The husbands worked in various jobs such as construction, agriculture, or industrial work, so they received different rates of income, and they sent remittances back to their households frequently. The variance in amounts remitted was due to the various jobs they worked in. Women whose husbands were working abroad lived in both nuclear and extended households. The different types of household they lived in demonstrated different responsibilities in housing activity. In cases where the women lived in extended households, they often had to look after their parents or their husband's parents. The women, on average, had 1-2 children, and they took care of the children and other household members at the same time. In addition, the women conducted a variety of occupations that included, government jobs, business, employees at farms or factories, and as farmers. The differences in their occupations caused the women to have different potential for management and decision making.

\section{Roles, in public space, of women whose husbands work abroad}

According to the various backgrounds of the women whose husbands were working abroad, they had a chance to participate in various activities in the public space. The activities they participated in consisted of political activity, community meeting activity, and merit making activity. Details of each activity are as follows. 
2.1) Political role of women whose husbands work abroad - The roles of women in politics referred to those who got involved in political activity and were elected as representatives of the community. The results showed that some women were able to be elected as members of the Subdistrict Administration Organization, a political organization at local level, with most positions held by male members. The steps towards the women participating in political activity started with them joining in community events or being members of local groups. Although it was another way to develop the community, participation in these activities allowed the women to play a role in the policy issuing and budget management of the organizations. The women had the chance to be a member of local organizations, and they were proud to develop their own communities. Another reason for the women to be elected was that they were locals who had lived in the community since childhood. This was the reason that the women were confident of being chosen, by the other community members, to be their representatives (Mammen and Paxson, 2000). Moreover, having their husbands working abroad allowed the women to have full rights and freedom to make decisions in any activities outside the household boundary. The women had more opportunities to play roles in the public space, and they were able to get more acceptances, from their parents and husbands, of a women's ability to participate in the public space. It was noted that women, firstly, had to create trust among their supporters, i.e. household members, cousins, or neighbors, before joining in political activity, in order to get acceptance from the community.

A secured economic status was another condition that encouraged the women in to the political space. When their neighbors in the community were in financial trouble, the women helped them by lending money. When the neighbors were happy with this, they would support the women to gain political roles. The income source that provided the women with stability of their financial status was the remittance from their husbands. The women managed the remittance for use on household expenditure. Some of the remittances were allocated for various purposes, such as savings, buying jewelry, or buying land for agricultural activity. Once they were able to manage their income and had financial stability for their own households, they then helped their neighbors and participated in community activity. This would give confidence to the women in performing roles in the political space. These findings supported Ullah's study (2017) that suggested that women, whose husbands work abroad, have become powerful political activists because they had a chance to prove their ability in politics, within the public space.

It can be seen that the women's decision to participate in political activities relates to many conditions, both individual and external. The women were confident to be representatives of the community due to the education they had received or the activities they participated in. They were free to make decisions and choose their own future.

2.2) Meetings with community: A space for representing social status - When husbands went to work abroad, the roles of their women in the community changed. Community activities such as meetings of the village committee and of the village fund once belonged to men because there was a traditional value that men could make important decisions better than women. Men have easier chances to get information and have access to resources, so men should be a better choice than women in attending the community meetings. When the men went to work abroad, the role of household representative shifted to the women or wives in attending the meetings and in decision making. 
At the village meetings, women whose husbands were working abroad attended the meetings as the representatives of their households. They attended the meetings to find ways to develop the village and shared their opinions with other members. Women who had a good education normally gained acceptance from other members, since these women would apply information and technology to their ideas and present them to the meeting, clearly. These findings supported Datta and Mishra (2011) who found that when husbands migrated to work abroad, some women had found roles in the village committees. Some, who were confident and had leadership skills, became the president of the committee and participated in decision making in the community. Women in the village committee applied modern technology and communication tools to find ways to develop the community. Many women knew how to use modern communication tools, since it was a way to get in touch with their husbands abroad. Participating in local organizations demonstrated the roles of women in the public area, and it gained the respect of others, towards the women. This was a way to secure their social status and empowered them to be confident, brave, and decisive in determining their future. An interview with a woman whose husband was working in South Korea is below.

"...Now I am a member of the village committee. I try to think what I can do for our community. I present several projects to the committee, and they mostly agree with me. They listen to me, although I am a woman. We can do it if we pay attention to..." (MS.Rose (fictitious name), 50 years old).

Although women took the role as representative of a household that had international migrants, in some migrant households, the role in the public space still belonged to men, such as the father in law or other male household members. This was found generally in households where the women had gained a low level education and they were still young. This reflected that education was a crucial condition for women in performing a role in the public area. Education improved women's ability and encouraged them to be a household representative, when given the opportunity.

2.3) Merit making activity: A space for creating identity - Making merit is a traditional practice linked to Buddhism. Women normally played a role in preparing food, while the men were setting up the ritual location at the temple and leading all steps of the ritual. When their men migrated to work abroad, participating in the rituals became another way for the women to create an identity and gain acceptance in society.

In the merit making rituals, women grouped themselves to make merit in order to show the stability of their financial status to support the ritual. On some occasions, they would act as the cohost of the ritual or as ritual fund raisers in order to raise donation money for the ritual. If they raised a large amount of money, they would get the admiration of the other community members. This was a way to build trust and to mobilize the social status of the women, as in a statement from an interview with a woman whose husband worked in Singapore.

"... in the recent merit making ritual we participated in, we were the leaders, separated from our husbands who worked in another country. Nowadays it is very easy to raise money. We just take a photo of the invitation letter and send it to our husbands. Our husbands then inform their colleagues in Singapore to make merit. We received much money, but less than from those who worked in Bangkok and South Korea..." (Ms. Chaba (fictitious name), 46 years old). 
In addition, it was noticed that clothes and jewelry were the indicators that represented the financial status of women. On the day before the ritual began, the women would prepare the clothes they would wear on the ritual day. Some ordered new fabric to make a dress. Women were defined by the clothes to ensure their confidence during the ritual. This demonstrated that the women paid attention to social expectations, they tried to get acceptance from society in various forms. These findings confirmed Desai and Banerji (2008), who found that Indian women were controlled by their husband's parents, although their husbands had migrated to work abroad. The women had not been freed in public areas.

Performing the merit making ritual was mostly acted out by wealthy women, who got remittance from their husbands regularly, and those who had well-managed financial status in their households. They had the confidence to perform their roles in public spaces.

\section{Conclusion and Recommendation}

A study of roles in the public space, of the women whose husbands work abroad, was conducted through the activities that the women participated in. The study reveals a view of women in the public space. According to the concept of gender role, the female is set "in place" within the household boundary, while the male represents roles in the public space. However, their husband's working abroad pushes the wives to play roles in the public space in 3 different activities which are 1) participation in political activity at local level, 2) participation in community meeting activity, and 3) participation in merit making activity.

The results indicated that having a husband working abroad pushed the women to improve their potential and to try to undertake roles in the public space. Although the communities they are living in still maintain traditional values and socio-cultural practices that rely on gender differentiation, women's roles have been changing due to a transition of the socio-economic context. Women, whose place was once within the household boundary, have now to perform roles in the community and political activities. It is concluded that when women have the chance to empower their potential, they are able to be leaders and play an important role in the public space.

Finally, it is clear that the husband working abroad has resulted in the women's role in the public space, for instance, political activity, community meetings, and merit making activity. These findings may be used to determine policies on development of the potential among women whose husbands work abroad, and develop leadership skills, education, and technology usage by women. Moreover, this can be used as a guideline to strengthen women in maintaining livelihood security while their husbands are working abroad.

\section{Acknowledgments}

This article uses information from the research study on the social practice of woman's left behind among migrant households. Thanks are extended to all of the women who left behind among migrant households helped provide useful information for this research.

\section{References}

Alesina, A., Giuliano, P., \& Nunn, N. (2013). On the Origins of Gender Roles: Women and the Plough. The Quarterly Journal of Economics, 128(2).

Atchawanitchakun, K., \& Thongsima, T. (2005). Women in the Sexual Rights Discourse. Bangkok: Amarin Printing and Publishing. 
Chantawanich, S. (2008). Sociological Theory. Bangkok: Chulalongkorn University Press.

Datta, A., \& Mishra, S. K. (2011). Impact of Male Migration on Women's Lives in Rural Bihar. The Indian Journal of Labour Economics, 54(3).

Desai, S., \& Banerji, M. (2008). Negotiated Identities: Male Migration and Left-Behind Wives in India. National Institutes of Health, 25(3), 337-355.

Karymshakov, K., \& Sulaimanova, B. (2017). Migration Impact on Left-behind Women's Labour Participation and Time-Use. United Nations University World Institute for Development Economics Research.

Liem, N., Yeoh, B. S. A., \& Toyota, M. (2006). Migration and the well-being of the 'left behind' in Asia. Asian Population Studies, 2(1), 37-44.

Limanont, P. (2008). Sexuality and Reproductive Health. Bangkok: College of Population Studies, Chulalongkorn University.

Mammen, K., \& Paxson, C. (2000). Women's Work and Economic Development. Journal of Economic Perspectives, 14(4).

Perraudin, A. (2016). Being a transnational mother while staying at home. Migrants' wives in Mexico City. Amérique Latine Histoire et Mémoire. Les Cahiers ALHIM.

Photisita, C. (2009). Sciences and Arts of Qualitative Research. Bangkok: Amarin Printing and Publishing.

Ramitanont, C. (1992). A Study of Women. Bangkok: Thammasat University.

Samutchak, P., Konkaew, T., \& Uden, R. (2017). The Well-being of Thai Family. Nakorn Pathom: Institute of Population and Social Research, Mahidol University.

Todaro, M. P. (1976). Internal Migration in Developing Countries. Geneva International Labour Office. Ullah, A. A. (2017). Male Migration and "Left-Behind" Women: Bane or Boom?. Environment and Urbanization ASIA, 8(1), 59-73.

Walby, S. (1991). Theorising Patriarchy. Oxford: Basil-Blackwell. 